\title{
Science Process Skills Characteristics of Junior High School Students in Lampung
}

\author{
Sunyono Sunyono \\ Chemistry Education Study Program, Faculty of Teacher Training and \\ Education, University of Lampung, Indonesia
}

Doi: 10.19044/esj.2018.v14n10p32 URL:http://dx.doi.org/10.19044/esj.2018.v14n10p32

\begin{abstract}
The quality of international education is measured through PISA and TIMSS results and the member countries are very concerned about their students' ability to work on PISA and TIMSS. Countries with low PISA and TIMSS ratings indicate that students' science process skills in this country are low, including in Indonesia. Therefore, this research needs to be done to see the characteristics of science process skill (SPS) of junior high school students, especially in Indonesia. This study involved 9th-grade students of the academic year 2016/2017 in three randomly selected districts. The number of subjects involved in the study was 120 randomly selected respondents. The research was conducted by survey method, by giving SPSs questions to respondents. The results showed that the SPS of junior high school students in Lampung Province-Indonesia is low. Students from schools in the capital and school areas close to the provincial capitals have the characteristics of SPSs on "observing" and "classifying" indicators in the "moderate" category. Students from distant areas of the provincial capitals, the characteristics of their SPSs are "low", for all indicators (observing, classifying, predicting, interpreting, and communicating).
\end{abstract}

Keywords: Science Process Skills, student characteristics, junior high school

\section{Introduction}

The rapid development of science and technology today requires people to provide human resources (HR) of quality and capable of competing globally. One effort to improve the quality of human resources is through quality science education because science is one discipline that examines three aspects, namely science as a scientific product, process, and attitude. Science as a product is a body of knowledge that includes concepts, principles, laws, and theories (Duschl, 2007). Science as a process plays a role in acquiring and developing knowledge through the SPSs. Learners should have the ability to 
do things using scientifically mastered processes and principles, learning to know and learning to do must be achieved in teaching and learning activities (UNESCO, 2012).

In fact, the quality of science education in some countries, especially in Indonesia is still categorized as low. Based on the assessment of the Education Development Index (EDI) indicates that Indonesia is ranked 64th out of 120 countries (UNESCO, 2012). The results of The United Nations Development Program (UNDP) in 2013 states that the Human Development Index (HDI) covering aspects of manpower, health, and education is ranked 121 out of 185 countries. Based on The Learning Curve Institute's report on the analysis of education performance, Indonesia is ranked 40th out of 40 countries of education mapping (Pearson, 2014).

Some research results have shown that the ability of teachers in the utilization of technology has not met the needs, the learning process is still conventional (teacher centered) that tend to be boring and less interactive and communicative in transferring knowledge, decreased motivation learners to study in the learning process, and the still minimal ability and skill of the educator understanding the contents of learning (Kirkup et al., 2007; Nentwig et al., 2007; Wahono, 2011). These studies focused more on the inability to understand the scientific concepts from the teacher, due to the learning of science that has not been able to facilitate the students' need for intellectual, social, and physical skills derived from the fundamental abilities that students actually already possessed within themselves. Such basic capabilities or skills among others include the ability or skill to observe or watch, which also includes calculating, measuring, classifying, and finding space or time relationships, making hypotheses, planning research, controlling variables, interpreting data, drawing inferences, predicting, applying and communicating (Hotaman, 2008). These skills are further identified as SPSs.

SPSs are a learning approach that focuses on developing the skills of students in processing knowledge, finding, and developing facts, concepts, and values that are scientifically needed (Semiawan, 1992). Through the SPSs, it is expected that the learning process can involve the students in finding and developing the knowledge they get independently in accordance with the current curriculum demands, namely one that is student-centered learning where the teacher is the facilitator (Suryani et al., 2015). Some research results indicate that students' inability to develop the ability to find and develop knowledge is due to the students' inability to understand the scientific concepts from teachers and failure to achieve learning in building the conceptual knowledge of students (Coll, 2008; Holbrook \& Rannikmae, 2009; Nentwig et al., 2007). This is a result of learning that is not yet capable of facilitating students to develop the SPSs that already exist in students. 
The learning process in schools in some countries with low PISA and TIMSS outcomes (including Indonesia) is still a major problem, as reflected in the results of PISA (Programme for International Student Assessment) study of Indonesian students from year to year shows that the trend of Indonesian students' science literacy has not shown any significant change. In 2015, the proportion correct grade of Indonesian students was still low, the average score earned for science was 493, therefore Indonesian students are ranked eighth lowest in the rank of 69 out of 76 PISA participating countries (OECD, 2016). These results do not vary much with PISA results in previous years. Similarly, the results of TIMSS (The Trends in International Mathematics and Science Study) in 2007 and 2011 in mathematics and science for 8th-grade junior high school student participants could only reach intermediate level (Kemdikbud, 2014). Similarly, for the TIMSS of 2015, shows Indonesian students are ranked 36 out of 49 countries in terms of performing scientific procedures in science subjects (OECD, 2016). The study thus indicates that the PISA and TIMSS results of Indonesian students always go hand in hand and doesn't move forward. The low science ability of Indonesian students is influenced by many factors such as the education system and curriculum, methods and learning models of teachers, learning facilities, learning resources, and teaching materials.

In accordance with the nature of science, the process of science learning should ideally rest on the scientific process. The scientific process involves a variety of SPSs (Towle, 1989: 16-31). When viewed from the level of SPSs, then observing skills is an initial skill in the process of science. This is followed by higher process skills such as the skills of measuring, classifying, and ending with the highest skill, namely, experimenting (Rezba et al., 1995: 1). SPSs can be used as alternative solutions to improve the effectiveness of science learning process, because learning that is oriented to SPSs will always involve cognitive or intellectual, manual, and social skills which, if integrated into a single learning unit, will form three dimensions of skills namely, basic skills, followed by the skills of data collection / developing / processing, and the highest is the skill to investigate or experiment (Bryce et al, 1990: 2). The development of SPSs enables students to acquire the skills necessary to solve everyday problems (Aydoğdu et al., 2014). Students who use the SPSs will have a positive attitude towards science. Therefore, learning that emphasizes the SPSs is essential to creating Science literacy in students (Espinosa, et al., 2013).

Learning with SPSs in junior high school requires a deep understanding of concepts because junior high school students are still in the development period of intelligence, creativity, language skills, learning motivation, and mental and physical conditions. In line with that, Karamustafaoglu (2011) argues that SPSs will not develop in students when 
the learning process does not accommodate the occurrence of scientific activities that can trigger the growth of scientific attitudes, sharpen the process skills in students, so as to become capable to actively participate in an investigation. Therefore, it is the responsibility of teachers to develop students' SPSs as supporters in developing the mastery of the concept of science, so as to provide better learning outcomes (Rizal, 2014).

Some studies have found that the low level of students' SPSs is due to the generally insufficient or low SPSs that science teachers and junior high school teachers have (Aydoğdu, 2006: Harty \& Enochs, 1985; Karsl1, et al. 2009; Lotter, et al., 2007, Sahin-Pekmez, 2001, Turkmen \& Kandemir, 2011) and teachers rarely use these skills in their classes (Oloruntegbe \& Omoifo, 2000), so that students' SPSs are difficult to develop. Similarly, most Indonesian Junior High School students have low SPSs. The Low SPSs of Indonesian students is reinforced by the results of Anam's (2014) research which conducted a study of thirty (30) representative students from $30 \mathrm{MI}$ (Madrasah Ibtidaiyah) in Sumedang Regency on Madrasah Science Competence (MSC) activities. The results showed that four (4) types of students' average process skills, namely observing, planning experiments, classifying, and making tables were in the less adept category, and were not adept in concluding skills. The same is also the research result of Sukarno et al. (2013) which states that the SPSs of junior high school students in Jambi on the skill to reach a conclusion, observation, predict, measure and classify is still low. Therefore, it is necessary to conduct research to obtain information about "Characteristics of SPSs of Junior High School Students in LampungIndonesia". The goal is to provide knowledge about the characteristics of students' SPSs to science learning on the study of the excretory system, so it can be used as a reference to improve the effectiveness of science learning in schools.

\section{Methodology Of Research Research design}

This research was conducted in Lampung Province-Indonesia with research design using the survey method. Research subjects were students from four (4) junior high schools in Lampung Province selected by using the random sampling technique. One class is taken from each school, namely 9thgrade students who have obtained learning materials on the human excretion system so that students who become the subject of this study amounted to 120 respondents.

\section{Research procedure / Data collection}

The research procedure was by collecting information gained from students' SPSs result to all students spread in four schools, including an junior 
high schools that is far from the provincial capital (SMPN 1 Sukoharjo and SMPN 1 Natar), junior high school close to the provincial capital ( SMPN 1 Gedongtataan), and junior high school in the provincial capital area (SMPN 16 Bandar Lampung). Furthermore, each of the junior high schools was coded: SMPN 1 Sukoharjo (SMP 1), SMPN 1 Natar (SMP 2), SMPN 1 Gedongtataan (SMP 3), and SMPN 16 Bandar Lampung (SMP 4). Data collection from the research subjects was conducted through tests and surveys.

\section{Instruments and Data analysis}

This study used a multiple-choice instrument test of 25 questions with 4 choices of answers. The test is used to measure the level of SPSs that includes observation ( 5 test points), classifying ( 5 test items), predicting ( 5 test points), interpreting ( 5 test points), and communicating (5 test points) skills. The SPSs (SPS) questions developed, before being used, was tested first through the validation of the expert (judgment expert). Based on the results it is found that the SPSs test questions that were developed could be used for data retrieval. Furthermore, the data has been collected by descriptive analysis, namely by calculating the percentage of students who get high, medium, and low-grade test results.

\section{Results Of Research}

Measurement of Mastery of students' SPSs in this research is related to a concept of SPSs. How deep the knowledge of the concept of SPSs of students' is indicated by the ability/skill of observing, classifying, predicting, interpreting, and communicating. The data obtained show that the average SPSs of students are at a relatively low level $(44.17 \% \pm 6.34)$. The SPSs for observing and classifying skills were grouped as moderate $(51.33 \% \pm 22.41$ and $50.67 \% \pm 22.59$ ), the skill of predicting, interpreting and communicating is grouped as low, $41.33 \% \pm 23.87 ; 39.33 \% \pm 21.99$; and $38.17 \% \pm 21.06$. Furthermore, in terms of the acquisition of SPSs for each school shows that most of the junior high school students in Lampung Province still have low SPSs on the concept of human excretion system. In sequence, junior high schools with students of high SPSs are SMP 2 (SMPN 1 Natar) 6.67\%; SMP 3 (SMPN 1 Gedongtataan) 6.67\%, and SMP 4 (SMPN 16 Bandar Lampung) $33.33 \%$. While students from SMP 1 (SMPN 1 Sukoharjo) do not have students with high SPSs achievement. In detail, the data of students' SPSs in some junior high schools in Lampung Province is illustrated in Figure 1 below. 


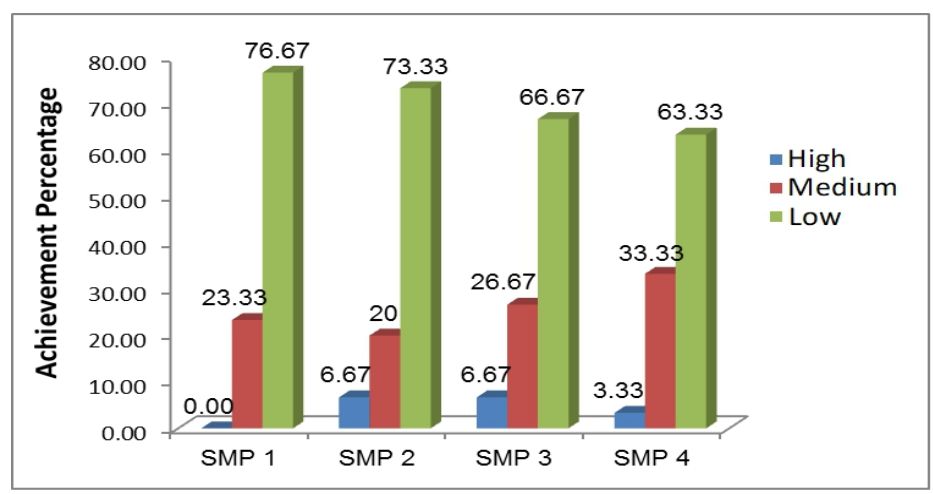

Figure 1. Percentage of students per school with the achievement of SPSs score on the high, medium, and low category.

From the perspective of SPSs for each indicator obtained, it also shows data that $50 \%$ of students have a SPS profile that is categorized as low for all indicators. Data about the SPSs profile for each indicator is illustrated in Figure 2 below.

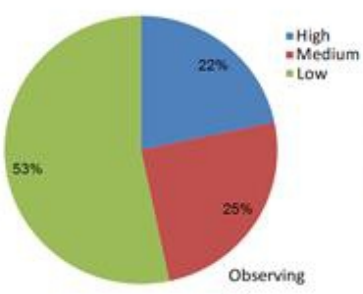

(a)

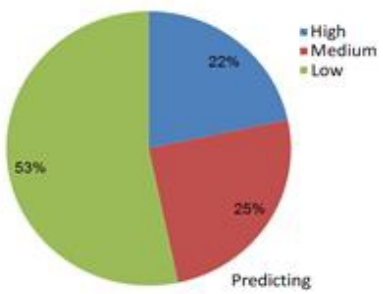

(c)

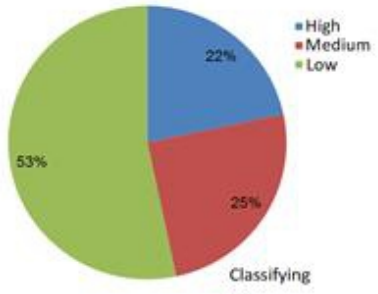

(b)

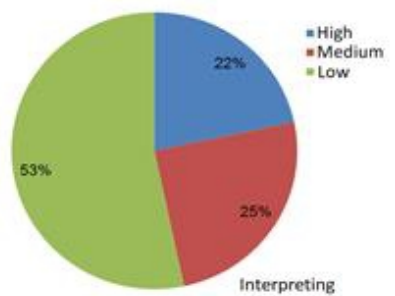

(d)

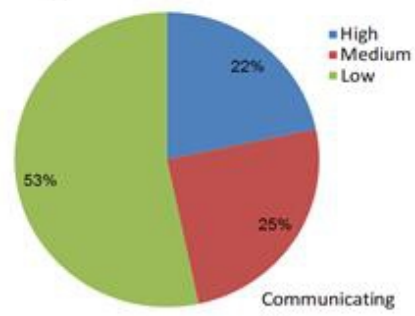

(e)

Figure 2. SPSs Achievement Percentage for each indicator with high, medium, and low category. (a). Observing indicator, (b) Classifying indicator, (c) Predicting indicator, (d) Interpreting indicator, and (e) Communicating indicator. 
From the perspective of the average achievement of each indicator of the students' SPSs which includes observing, classifying, predicting, interpreting, and communicating, one finds that only in the observing and classifying indicator does students' achievement reach the "medium" category (>50\%). The analysis results of each indicator as a whole are presented in detail in Figure 3 below.

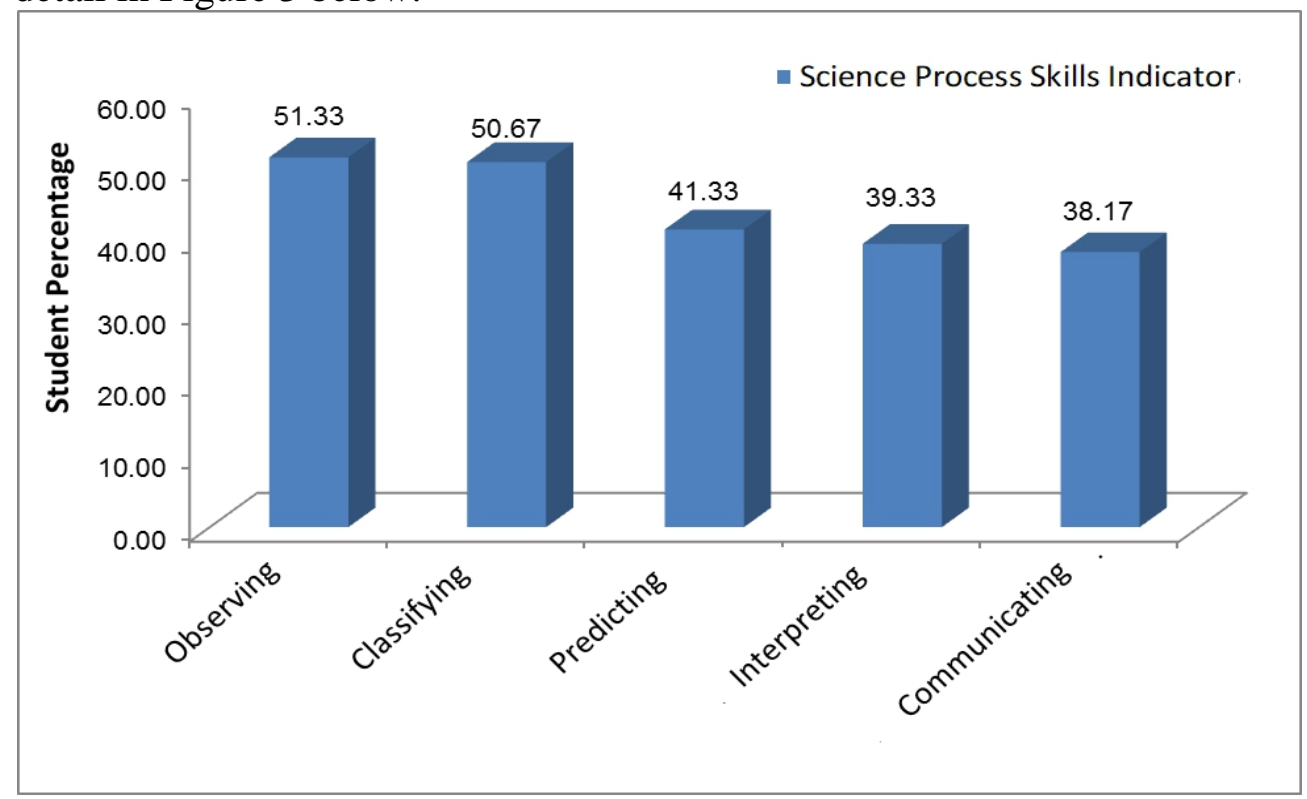

Figure 3. Percentage of students with the SPSs achievement for each indicator.

\section{Discussion}

The results showed that the SPSs of learners in Lampung Province are categorized as low. The low SPSs are influenced by many factors, among others the education system and curriculum, methods and learning models from the teachers, learning resources, and teaching materials. Thus, the low SPSs of junior high school students in Lampung Province indicates that science learning process in schools has not been able to facilitate the students to develop the SPSs that students actually possess.

The low SPSs of students were due to not being trained with problems of high-level thinking skills during learning, such as problem-solving, analysis, and interpretation. Students were not trained in reading observational data in the tabular form or describing observational data obtained from test results. This is in line with the research of Temiz, et al (2006) which states that when testing SPSs five basic capabilities will emerge, which are naming, generalizing data, interpreting data, identifying variables, and formulating hypotheses.

In reference to the results of the study, it indicates that the average level of student SPS mastery is of the "low" criterion with the best SPS achievement 
on the observing and classifying indicator with the "medium" criterion and the indicators of interpretation, prediction, and communication received the lowest achievement level with the "low" criterion..

The analysis results on the observing and classifying indicators are categorized as high. Students have been able to use various senses to collect or use relevant facts in explaining phenomena and students can also classify facts to find differences, similarities; contrasting characteristics; compare; looking for basic grouping or classification. This means that students have been able to understand the study materials of the human excretion system through SPSs exercise problems. According to Dirks, at al (2006) SPSs can be taught to students in the form of exercises in making graphs, analyzing data, creating research designs, writing scientific papers, and scientific discussions. According to Buntod, at al (2010) learning with SPS should be routinely practiced with the goal of bringing out individuals who can conduct research, ask questions, achieve scientific knowledge by using scientific thought, and even use knowledge to solve problems encountered in everyday life.

The ability to classify data, based on the results of written tests are categorized in the medium criterion. This indicates that students' understanding of the structure and function of bones is good so that students are able to properly classify bones. This is also supported by the materials taught to students, which is about the human motion system so that students can directly explore parts of their motion system in finding answers to the questions posed. As stated by Warianto (2011: 14), it is important to develop classification skills to make it easier to identify a problem.

Interpretation ability assessment by making conclusions from observational data shows better results. This shows that students prefer to interpret data presented in the form of description and supported by a theory underlying the data. This is in line with the views of Pie (Johnstone and Robinson, 2012: 2) which state that communication is based on symbolic values and with different expressing processes such as word, voice, body language, writing, and pictures. All accumulated into the experience and transmitted between individuals, generations, times, races, and cultures in several forms such as speaking, writing, body language or symbols.

The ability to predict by estimating something that has not occurred based on an existing tendency or pattern to answer a question is still very low, students are still unable to relate the what usually occurs and possibilities that may occur with reference to the student's previous knowledge.

Student ability to communicate data in graphs also shows poor results as indicated by written tests results on questions related to communication with the low criterion. It also shows students' understanding of data about the human excretion system that is still categorized as low, so that students have 
not been able to change the form of data being presented into a written statement as a conclusion whilst not changing its meaning.

When viewed from the analysis of the achievement of the SPSs for each school (Figure 1) shows that students coming from schools residing in the provincial capitals (SMP 4) have a profile of SPSs for the concept of excretory systems that are similar to those of the school which is close to the provincial capital (SMP 3). Furthermore, students from schools far from the provincial capital have lower SPSs characteristics, especially for indicators of predicting, interpreting, and communicating. These varied results indicate that selecting locations in 4 different schools turned out to provide the fact of differences in students' ability to understand the concepts of human excretory systems, thus their SPSs achievement becomes lower. Differences in location, background, knowledge, and school/home environment have a role in influencing their competence in the form of SPSs. Hariadi (2009) also states that the competence of science is influenced by several factors such as the environment and the student's knowledge. Another thing that can be expressed from the results of this study is the average ability to provide reasons, predictions, or communication, where the average score of SPSs in each question is $0-4$, but the ability of students is only within the range 0-2.

The characteristics of the SPS of Junior High School students in Lampung Province is only on the skills of observing and classifying with a "medium" category. For indicators of predicting, interpreting and communicating skills, the characteristics of the students' SPSs are still categorized as low. The low characteristic of the SPSs in the predictive, interpreting, and communicating indicators is indicated to be due to the student inability to understand the human excretion system, especially in explaining the related internal process in the body in relation to excretion organs, excretion system abnormalities, and excretion process of metabolic waste remaining substances that are no longer needed by the body. In addition, students also have not been able to predict the presence of residual substances that will be excreted through urine, sweat, or breathing. Most students only memorize the parts of the organs and processes in the excretory system, so students are prone to forget and are not sensitive to problems related to the human excretion system. This finding is consistent with the findings of Luky (2014: 3) which states that in science learning, most students only memorize the parts of the organs and processes in the human excretion system but are unable to apply them in real situations, thus students are prone to forget and insensitive to the problems in human life associated with the excretory system. These findings suggest that students have not been able to relate concepts that have been studied with real-world phenomena and concepts being studied. This indicates that the application of the conceptual change process of students to science learning has not been done by science teachers. The reason is that 
most science teachers still do not have a sufficient level of understanding of the conceptual change process, so that science learning is still limited to the delivery of material according to the curriculum (Gamze \& Mustafa, 2014).

It is very important for the teacher to know about the findings on the SPSs characteristics, so they can apply an appropriate learning strategy. Given that learning by prioritizing SPSs will make students active in learning and teachers can easily persuade students to process new information through concrete experience and can facilitate students to achieve the goals of science learning, so that the learning objectives that have been formulated from each basic competency can be achieved and students are able to do the study thoroughly. Learning by being oriented to SPSs can also encourage students to discover their own facts, concepts of knowledge and foster the attitudes and values of student personality. Therefore, the SPSs is an important component in the implementation of learning because it can affect the development of students' knowledge (Ango, 2002). This SPS has a function as an effective competency to study science and technology, problem-solving, individual and social development (Akinbobola, 2010: 234). This SPS is very important because it can assist students in translating abstract concepts into concrete experiences (Ango, 2002: 11).

\section{Conclusion}

Based on data analysis results, it can be concluded that the SPSs of Junior High School students in Lampung Province-Indonesia are categorized as low. Each student coming from a different school possessed different SPSs characteristics. Students from schools in the capital and schools near provincial capitals have the same SPSs characteristics, namely "observing" and "classifying" but still in the "medium" category. Students in regions farther from provincial capitals have SPSs characteristics that are still categorized as "low", either on the indicators of observing and classifying, as well as on higher indicators, namely predicting, interpreting and communicating. Overall, students' SPSs only reached the indicators of observing and classifying and not achieving a higher indicator yet.

\section{Acknowledgements}

This article is a part of the research (publication) funded by Pascasarjana Grant from BLU of University of Lampung, Ministry of Research, Technology and Higher Education- Indonesia, 2017. The best gratitude to the University of Lampung for all the facilities for the success of this research, as well as to the Local Governments of Bandar Lampung City; South Lampung Regency; Pesawaran Regency; Pringsewu Regency, and all teachers, headmasters, school committees, and students for their valuable contributions. 


\section{References:}

1. Anam, R. S., (2014). Analisis Keterampilan Proses Sains Siswa Madrasah Ibtidaiyah di Kabupaten Sumedang (Science Process Skills Analysis of Madrasah Ibtidaiyah Students in Sumedang Regency). Prosiding Konferensi Pendidikan Dasar. SPs UPI, 20, 274 - 282.

2. Ango, M. L. (2002). Mastery of Science Process Skills and Their Effective Use in the Teaching of Science: An Educology of Science Education in the Nigerian Context. International Journal of Educology, 1 (16): 11-20.

3. Akinbobola, A. O., \& Afolabi, F. (2010). Analysis of Science Process Skills in West African senior secondary school certificate physics practical examinations in Nigeria. American-Eurasian Journal of Scientific Research, 5(4), 234-240.

4. Aydoğdu, B. (2006). İlkogretim fen ve teknoloji ogretiminde bilimsel süreç becerilerini etkileyen degişkenlerin belirlenmesi (Identification of variables effecting Scince Process Skills in primary science and technology course). Unpublished Master Thesis. Dokuz Eylül University, Educational Sciences Institute, İzmir.

5. Aydoğdu, B., Erkol, M., And Erten, N. (2014). "The Investigation Of Science Process Skills Of Elementary School Teachers In Terms Of Some Variables: Perspectives From Turkey". Asia-Pacific Forum On Science Learning And Teaching. 5(1). Avalilable on: https://www.eduhk.hk. Access: Agustus 5, 2017.

6. Bryce, T.G.K., J. McCall., J. MacGregor., I.J. Robertson., \& R.A.J., Weston. (1990). Techniques For Assessing Process Skills In Practical Science: Teacher's Guide. London, Oxford: Heinemann Educational Books.

7. Buntod, P. C., Suksringam, P., \& Singseevo, A. (2010). Effects of learning environmental education on Science Process Skills and critical thinking of mathayomsuksa 3 students with different learning achievements. Journal of Social Sciences, 6(1), 60-63.

8. Coll, R.K. (2008). Chemistry Learners' Preferred Mental Models for Chemical Bonding. Journal of Turkish Science Education. 5 (1), p. 22 $-47$.

9. Dirks, C. \&Cunningham, M. (2006). Enhancing Diversity in Science: Is Teaching Science Process Skills the Answer?. CBE-Life Sciences Education. Journal. Vol. 5, 218 -226.

10. Duschl, R. A., Schweingruber, H. A., \& Shouse, A.W. (2007). Taking Science to School: Learning and Teaching Science in Grades K-8. National Academies Press.Washington DC.

11. Espinosa, A. A., Monterola, S. L. C., \& Punzalan, A.E. (2013). Careeroriented performance tasks in chemistry: Effects on students' 
integrated Scinece Process Skills. Cypriot Journal of Educational Sciences, 8(2), 211-226.

12. Feyzioğlu, B. (2009). An investigation of the relationship between Science Process Skills with efficient laboratory use and science achievement in chemistry education. Journal of Turkish Science Education, 6(3), 114.

13. Gamze, A. \& Mustafa S.K. (2014). Teaching Processes and Methods Suggested bu Science Teachers for Overcoming Alternative Conceptions about Genetics. The New Educational Review. 35 (2), 66 -81 .

14. Hariadi, E. (2009). Faktor-Faktor yang Mempengaruhi Literasi Sains Siswa Indonesia Berusia 15 Tahun (Factors Affecting Science Literacy of Indonesian Students Aged 15 Years). Jurnal Pendidikan Dasar. 10 (1). pp 29-43. Avalilable on: http://ejournal.unesa.ac.id/mobile/. Access Oktober 28, 2015.

15. Harty, H., \& Enochs, L.G. (1985). Toward reshaping the inservice education of science teachers. School Science and Mathematics, 85(2), 125-135.

16. Holbrook, J. \& Rannikmae, M. (2009). The meaning of scientific literacy. International Journal of Enviromental \& Science Education, 4 (3), 275-288.

17. Hotaman, D. (2008). The Examination of the Basic Skill Levels of the Students in Accordance with the Perceptions of Teachers, Parents and Students. Online Submission, 1(2), 39-55.

18. Johnstone, F. \& W. Robinson. (2012). An Instrument For Assesing Communication Skills of Healthcare and Human Services Students. The Internet Journal of Allied Health Science and Practice. Vol. 10. No. 4. pp 2-3. Available on: http://ijahsp.nova.edu/articles/Vol10Num4/pdf/ Johnston.pdf. Access: November 16, 2016.

19. Karamustafaoğlu, S. (2011). Improving the Science Process Skills Ability of Prospective Science Teachers Using I Diagrams. Eurasian Journal of Physics and Chemistry Education, 3(1), 26-38.

20. Karsl1, F., Şahin, C., \& Ayas, A. (2009). Determining science teachers' ideas about the Science Process Skills: A case study. Procedia Social and Behavioral Science, 1, 890-895. doi:10.1016/j.sbspro.2009.01.158.

21. Kemdikbud. (2014). Materi Pelatihan Guru Implementasi Kurikulum 2013 (Teacher Training Materials Curriculum Implementation 2013). Badan Pengembangan SDM Pendidikan dan Kebudayaan. Penjamin Mutu Pendidikan. Kemdikbud. 
22. Kirkup, C., Schagen, I., Wheater, R., Morrison, J. and Whetton, C. (2007). Use of an Aptitude Test in University Entrance - a Validity Study: Relationships between SAT® Scores, Attainment Measures and Background Variables (DfES Research Report 846). London: DfES [online].

http://www.dfes.gov.uk/research/data/uploadfiles/RR846.pdf. Access: November 16, 2016

23. Lotter, C, Harwood, W. S., \& Bonner, J. J. (2007). The influence of core teaching conceptions on teachers' use of inquiry teaching practices. Journal of Research in Science Teaching, 44, 1318-134.

24. Luky, I. (2014). Pengembangan Lembar Kegiatan Siswa Berpikir Kritis Pada Materi Sistem ekskresi Manusia (Development of Student Activity Sheets for Critical Thinking on Human Excretion System Material). Skripsi tidak diterbitkan (Unpublished Thesis). Surabaya: Unesa.

25. Nentwig, P.; Parchmann, I., Grasel; C., Ralle, B. \& Demuth, R. (2007). Chemie im Kontext - A New Approach to Teaching Chemistry; Its Principles and First Evaluation Data. Journal of Chemical Education (JChemEd), 84 (9), pp. 1439-1444.

26. Oloruntegbe, K.O. \& Omoifo C.N. (2000) Assessing process skills in STME Going Beyond Paper and Pencil Tests. Educational Thoughts, 1 (1), pp 25-36.

27. Organisation for Economic Cooperation and Development (OECD). (2013). Snapshot of performance in mathematics, reading and science. (online). Available on: http://www.oecd.org/pisa/ keyfindings/PISA2012-results-snapshot-Volume-I-ENG.pdf, Access November 15, 2015.

28. Organisation for Economic Cooperation and Development (OECD). (2016). PISA 2015 Result in Focus. OECD Publishing, OECD Secretary-Genera. Available on: https://www.oecd.org/pisa/ pisa2015-results-in-focus.pdf. Access: September 15, 2017.

29. Pearson. (2014). Education and Skills for Life. (Onlinea). Available On: $\quad$ http://thelearningcurve.pearson.com/2014-report-summary. Access: Mart 22, 2017.

30. Rezba, et.al. (2003). Learning and Assessing Science Process Skills $4^{\text {th }}$ Edition. Richmond: Kendall/Hunt Publishing Company.

31. Rizal, M. (2014). Pengaruh Pembelajaran Inkuiri Terbimbing dengan Multi Representasi terhadap Keterampilan Proses Sains dan Penguasaan Konsep IPA Siswa SMP (The Influence of Guided Inquiry Learning with Multiple Representation of Process Skills of Science and Mastery of Science Concept of Junior High School Students). Jurnal Pendidikan Sains, 2(3), 159-165. 
32. Şahin-Pekmez, E. (2001). Fen öğretmenlerinin bilimsel süreçler hakkindaki bilgilerinin saptanmast (Identification of science teachers' knowledge of scientific processes). Maltepe Üniversitesi, Eğitim Fakültesi, Yeni Bin Yılın Başında Türkiye'de Fen Bilimleri Eğitimi Sempozyumu, İstanbul.

33. Semiawan, C (1992). Pendekatan Keterampilan Proses (Process Skills Approach). Jakarta. Gramedia Press.

34. Sukarno, Permanasari, A., dan Hamidah, I., (2013). The Profile of Science Process Skills (SPSs) Students at Secondary High School (Case Study in Jambi). International Journal of Scientific Engineering and Research (IJSER). Vol. 1(1). Available on: www.ijser.in. Access: April 12, 2016.

35. Suryani, A., Siahaan, P., dan Samsudin, A. (2015). Pengembangan Instrumen Tes untuk Mengukur Keterampilan Proses Sains Siswa SMP pada Materi Gerak (Development of Test Instruments for Measuring Skills of Science Processes of Junior High School Students on Motion Material). Prosiding Simposium Nasional Inovasi dan Pembelajaran Sains. Date 8 * 9 Jun 2015. Bandung. pp. 217 - 220.

36. Temiz, K.B., et al. (2006). Development and Validation of a Multiple Format Test of Science Process Skills. Internasional Education Journal, 7(7), 1007-1027.

37. Towle, A. (1989). Modern Biology (Keterampilan Proses: Bagaimana Mengaktifkan Siswa dalam Belajar (Process Skills: How to Activate Students in Learning). Jakarta. Grasindo Press.

38. Turkmen, H., \& Kandemir, E. M. (2011). Öğretmenlerin bilimsel süreç becerileri öğrenme alanı algıları üzerine bir durum çalışması (A case study on the teachers' scientific process skills learning domain perceptions). Journal of European Education, 1(1).

39. UNESCO. (2012). Working paper series on mobile learning: turning on mobile learning in Latin America. Paris. UNESCO.

40. Warianto, C. (2011). Biologi Sebagai Ilmu (Biology As a Science). Avalilable on: http://skp.unair.ac.id/reposit ory/guruindonesia/ biologiSeb agaiIlmu_ChaidarWarianto_2 5.pdf. Access: Oktober 2015.

41. Wahono, W. (2010). Pengembangan Model Pembelajaran "MiKiR" pada Perkuliahan Fisika Dasar untuk Meningkatkan Keterampilan Generik Sains dan Pemecahan Masalah Calon Guru SMK Program Keahlian Tata Boga (Development of "MiKiR" Learning Model at Basic Physics Lecture to Improve Generic Science Skills and Problem Solving SMK Teachers Candidate Program). Disertasi tidak dipubilaksikan (Unpublished Dissertation). Program s3 Pendidikan IPA. Sekolah Pascasarjana UPI. Bandung. 